Molecular detection of natural Babesia bovis infection from clinically infected and apparently healthy water buffaloes (Bubalus bubalis) and crossbred cattle

Mahmmod, Yasser

Published in:

Journal of Buffalo Science

DOI:

10.6000/1927-520X.2012.01.01.10

Publication date:

2012

Document version

Publisher's PDF, also known as Version of record

Citation for published version (APA):

Mahmmod, Y. (2012). Molecular detection of natural Babesia bovis infection from clinically infected and

apparently healthy water buffaloes (Bubalus bubalis) and crossbred cattle. Journal of Buffalo Science, 1(1), 5560. https://doi.org/10.6000/1927-520X.2012.01.01.10 


\title{
Molecular Detection of Natural Babesia bovis Infection from Clinically Infected and Apparently Healthy Water Buffaloes (Bubalus bubalis) and Crossbred Cattle
}

\author{
Yasser S. Mahmmod ${ }^{*, 1,2}$ \\ ${ }^{1}$ HERD: Centre for Herd-oriented Education, Research and Development, Department of Large Animal \\ Sciences, Faculty of Life Sciences, Copenhagen University, Grønnegårdsvej 2, DK-1870 Frederiksberg C, \\ Copenhagen, Denmark \\ ${ }^{2}$ Department of Animal Medicine, Faculty of Veterinary Medicine, Zagazig University, Zagazig City, Sharkia \\ Province 44511, Egypt
}

\begin{abstract}
Babesia bovis (B. bovis) is a major causative agent of bovine babesiosis, with a considerable worldwide impact. The objective of this study was to evaluate the usefulness of PCR assay and microscopical examination (ME) for detection of $B$. bovis in naturally infected and apparently healthy water buffaloes and crossbred cattle under field circumstances from Sharkia province of Egypt. A total 34 animals (20 crossbred cattle and 14 buffaloes) were clinically and laboratory investigated during the period from March to August 2008. Fifteen animals showed symptoms of bovine babesiosis while 19 animals were apparently healthy. Two blood samples were collected from each animal; one was used for preparation of Giemsa-stained smears for ME while the other sample was used for DNA extraction and PCR testing. Out of 34 cattle and buffaloes, ME identified 13 animals (38.2\%) as infected by $B$. bovis whereas PCR identified $29(85.3 \%)$. B. bovis infected animals showed high fever, anaemia, jaundice, haemoglobinuria, and accelerated heart and respiratory rates. Out of 15 animals clinically infected, PCR identified 14 animals $(93.3 \%)$ as infected while ME identified only, 8 animals (53.3\%). Out of 19 animals apparently healthy, 5 animals (26.3\%) were identified as infected by ME meanwhile 15 animals (78.9\%) were identified by PCR. In conclusion, our findings demonstrated that water buffalos are likely to have a natural tolerance to $B$. bovis pathogen and/or more likely to be persistent carriers which were not picked up by microscopy. The severity of clinical symptoms of $B$. bovis infection on water buffaloes was less than the severity of clinical symptoms appeared on cattle. PCR assay is more sensitive technique than microscopical examination for detection of $B$. bovis in both clinically infected and apparently health cattle and water buffaloes which suggests its use as a routine technique for diagnosis of bovine babesiosis.
\end{abstract}

Keywords: Babesia bovis, natural infection, PCR, microscopic examination, water buffaloes, carriers.

\section{INTRODUCTION}

Bovine babesiosis is the most important tick-borne disease of cattle worldwide, affecting cattle industries in tropical and subtropical parts [1, 2]. It is caused by ticktransmitted haemoprotozoan Babesia bovis (B. bovis) of the genus Babesia, family Babesiidae, order Piroplasmida, phylum Apicomplexa and generally, it characterized by a significant morbidity and mortality worldwide [3]. B. bovis commonly called piroplasms because of the pear-shaped elements found within the infected red blood cells. In natural conditions, B. bovis transmitted by the tick Boophilus microplus, although transmission may occur by other tick species [4]. The prevalence of the ticks and babesiosis are among the most important factors hindering the introduction of more productive livestock due to high rates of morbidity, mortality, costs of prophylactic measures and epidemiological control [5]. It is estimated that mortality rates in cattle infected by $B$. bovis without treatment could reach $70-80 \%$ [6]. Animals that survive

*Address corresponding to this author at the Department of Large Animal Sciences, Faculty of Life Sciences, Copenhagen University, Grønnegårdsvej 2, 1870 Frederiksberg C, Copenhagen, Denmark; Tel: +45 527952 48;

Fax: +45 353330 22; E-mail: yasser@life.ku.dk after infection with $B$. bovis become low-level carriers of the parasites and serve as reservoirs for further transmission. Although Giemsa-stained blood smear examination is considered to be the "Gold Standard Test" for the diagnosis of babesiosis, however, the parasites' visualization may be difficult in cases of low parasitaemia which need more expertise to examine these [1,7]. However, the traditional methods for detection of $B$. bovis in these animals depend on indirect serological tests such as the indirect immune fluorescence antibody test (IFAT) [8], but these tests exhibited low sensitivity and specificity $[9,10]$ due to cross reactivity of antibodies directed against other species of piroplasms [11]. Moreover, it was found that antibodies tend to disappear in long-term carriers. Nucleic acid probes for $B$. bovis and $B$. bigemina have been developed from repetitive genomic DNA of both parasites [12, 13]. Although, these probes increased the sensitivity of parasite detection but they were unlikely to be adequate for the detection of carrier animals [14]. Consequently, Polymerase Chain Reaction (PCR) has been successfully employed for the detection of $B$. bovis $[9,15]$ and $B$. bigemina [10]. 
In Egypt, bovine babesiosis is caused mainly by $B$. bigemina and $B$. bovis and considered as the most important and endemic parasitic disease affecting cattle [16]. They have a significant economic impact on meat and milk production and on livestock management [17]. The rapidly changing patterns of demand for cattle and its products point to cattle production being an important and increasing component of the Egyptian agriculture economy which required improving cattle health. Although, Egyptian Native cattle breed is a disease-resistant breed to a considerable limit but their milk and meat production are not sufficient for the increasing demands by Egyptian consumers. Importation of European HolsteinFriesian cattle breed which characterized by high milk and meat production, was an important solution to compensate the reduction in the dairy and beef production in the recent decades but these exotic breed was a disease-susceptible breed. Egyptians farmers cross breeding between the European Holstein-Friesian cattle breed and Egyptian Native cattle breed to get a disease-resistant breed with high milk and meat production.

Water buffaloes (Bubalus bubalis) posing an important source of various human needs, such as meat, horns, hides, milk and milk products, leather, land plowing, and transportation of people and crops [18]. Due to the fact that water buffaloes are raised together with cattle, among which bovine babesiosis is highly prevalent [19], they might be potential carriers for Babesia parasites. In Egypt, there is not a clear control program for combating blood parasites in general and babseiosis in particular. Therefore, a scheme of diagnosis and identification is needed. Although, $B$. bovis infection was experimentally investigated in splenectomised buffaloes [20] and $B$. bigemina in crossbred [21] but this study is undertaken in an effort to furnish information about molecular detection of natural infection with $B$. bovis in water buffaloes and crossbred cattle under field circumstances. The objective of the present study was to evaluate the usefulness of PCR assay and microscopical examination for detection of $B$. bovis in naturally infected and apparently healthy water buffaloes and crossbred cattle under field circumstances from Sharkia province of Egypt.

\section{MATERIAL AND METHODS}

\section{Animals and Sampling}

This study was conducted on 34 animals (20 crossbred cattle and 14 water buffaloes) of both sexes, ageing from 2 to 5 years old, (Table 1). Two blood samples from each animal were collected from Jugular vein into EDTA-containing tubes. The first blood sample was immediately used to make Giemsa-stained smears for microscopical examination (ME) while the second blood sample were frozen at $-70^{\circ} \mathrm{C}$ prior to DNA extraction and PCR testing. Animals were belonged to unorganized small-scale farming in the rural areas; Shobk Basta, Beny Aamar, El-Aslogy and Tel Basta around Zagazig city, Sharkia province. The common available foods for animals under the study were mainly consisted of Barseem (Trifolium alexandrinum), rice or wheat straw and concentrate mixture (1-2 kg/head/day).

\section{Clinical Examination}

Cattle and buffaloes were examined clinically and laboratory at Veterinary Teaching Hospital, Faculty of Veterinary Medicine, Zagazig University during the period from March to August 2008. A total 15 animals (11 cattle and 4 buffaloes) showed symptoms of bovine babesiosis from persistent fever, pale mucous membranes, and anorexia with or without history of bloody urine, in addition to presence of ticks of different stages on different parts of the animals' body. A total 19 animals ( 9 cattle and 10 buffaloes) were apparently healthy but were examined carefully both clinically and parasitologically $[22,23]$.

\section{Microscopic Examination}

The first blood sample from each animal was used to prepare thin blood films immediately, after taking the blood samples. Blood smears were allowed to dry by

Table 1: Number of Water Buffaloes and Crossbred Cattle Examined During Period from March to August 2008 with their Identification into Clinically Infected and Apparently Healthy

\begin{tabular}{|c|c|c|c|}
\hline Species & Clinically infected & Apparently healthy & Total number \\
\hline \hline Crossbred cattle & 11 & 9 & $20(58.8 \%)$ \\
\hline Water buffaloes & 4 & 10 & $14(41.2 \%)$ \\
\hline Total & $13(38.2 \%)$ & $21(61.8 \%)$ & $34(100 \%)$ \\
\hline
\end{tabular}


air then fixed by using methanol for about 3-5 minutes, allow them to dry by air after fixation step then stained with Giemsa stain diluted at $8 \%$ with distilled water for about 30-45 min. They were dried by air and examined on Olympus microscope using oil immersion lens at x1000 magnification [22]. Blood films were examined for $B$. bovis at $1 / 4-1 / 2$ inch from the end of the film and transferred from one side of film to other (crosssectional method) to give constant and representative examination. Each blood film and at least twenty microscopic fields of each slide were examined twice before being considered negative.

\section{DNA Extraction}

The DNA was extracted from each sample by chloroform- isoamyl extraction method (All buffers used according to [24]. Babesia genomic DNA was extracted from the second blood samples which were frozen at $70^{\circ} \mathrm{C}$. To each $1 \mathrm{ml}$ sample, add $0.8 \mathrm{ml} 1 \mathrm{X} \mathrm{SSC}$ buffer, and mix. Centrifuge for 1 minute at $12,000 \mathrm{rpm}$ in a microcentrifuge. Remove $1 \mathrm{ml}$ of the supernatant and discard into disinfectant. Add $1 \mathrm{ml}$ of $1 \mathrm{X}$ SSC buffer, vortex, and centrifuge as above for 1 minute, and remove all of the supernatant. Add 375 ul of $0.2 \mathrm{M}$ $\mathrm{NaOAc}$ to each pellet and vortex briefly. Then add $25 \mathrm{ul}$ of $10 \%$ SDS and $5 \mathrm{ul}$ of proteinase $\mathrm{K}(20 \mathrm{mg} / \mathrm{ml} \mathrm{H} 2 \mathrm{O})$ (Sigma P-0390), vortex briefly and incubate for 1 hour at $55^{\circ} \mathrm{C}$. Add $120 \mathrm{ul} \mathrm{phenol/chloroform/isoamyl} \mathrm{alcohol}$ and vortex for 30 seconds. Centrifuge the sample for 2 minutes at $12,000 \mathrm{rpm}$ in a microcentrifuge tube. Carefully remove the aqueous layer to a new $1.5 \mathrm{ml}$ microcentrifuge tube, add $1 \mathrm{ml}$ of cold $100 \%$ ethanol, mix, and incubate for 15 minutes at $-20^{\circ} \mathrm{C}$. Centrifuge for 2 minutes at $12,000 \mathrm{rpm}$ in a microcentrifuge. Decant the supernatant and drain. Add 180 ul 10:1 TE buffer, vortex, and incubate at $55^{\circ} \mathrm{C}$ for 10 minutes. Add 20 ul $2 \mathrm{M}$ sodium acetate and mix. Add $500 \mathrm{ul}$ of cold $100 \%$ ethanol, mix, and centrifuge for 1 minute at $12,000 \mathrm{rpm}$ in a microcentrifuge. Decant the supernatant and rinse the pellet with $1 \mathrm{ml}$ of $80 \%$ ethanol. Centrifuge for 1 minute at $12,000 \mathrm{rpm}$ in a microcentrifuge. Decant the supernatant, and dry the pellet in a SpeedyVac for 10 mi-nutes (or until dry). Resuspend the pellet by adding 200 ul of 10:1 TE buffer. Incubate overnight at $37 \mathrm{C}$, vortexing periodically to dissolve the genomic DNA. All DNA samples were stored at $-20^{\circ} \mathrm{C}$ for PCR amplification.

\section{PCR Amplification}

Positive control samples representing Babesia spp. and $B$. bovis were kindly provided by Prof. Adel Goher, Department of Clinical Pathology, Faculty of Veterinary Medicine, Cairo University, Egypt.

PCR reactions were performed in a volume of $50 \mu \mathrm{l}$, containing PCR buffer $(50 \mathrm{mM} \mathrm{KCl}, 10 \mathrm{mM}$ Tris- $\mathrm{HCl}, 4$ $\mathrm{mM} \mathrm{MgCl2}$ ), $200 \mu \mathrm{M}$ of each dNTPs, 80 pmol of each primer (Table 2) and $2 \mathrm{U}$ of Taq DNA polymerase enzyme (Promega). The conserved primers for amplifying Babesia spp. were synthesized as described by [10] while the primers specific for $B$. bovis were synthesized as described by [15] (Table 2). Amplification was performed in a thermocycler (Coy Corporation) under the following conditions: $94^{\circ} \mathrm{C}$ for 5 minutes (initial denaturation), followed by 30 cycles of $94^{\circ} \mathrm{C}, \quad 30 \mathrm{sec}$ (denaturation), $49^{\circ} \mathrm{C}, 1.5$ minutes (annealing), $72^{\circ} \mathrm{C}, 3$ minutes (extension) and a final extension of $72^{\circ} \mathrm{C}$ for 10 minutes. About $5 \mu \mathrm{l}$ of genomic DNA was added to each PCR reaction. Positive control and negative control (with no DNA template) were always included for PCR amplification. The amplification products were electrophoresis on $1.5 \%$ agarose gel containing ethidium bromide. The length of the amplified products was estimated by using a base pair standard (100 base-pair ladder, Amersham Biosciences) and the amplified products were visualized with an UV trans-illuminator (Sigma).

\section{RESULTS}

Water buffaloes and cattle identified as $B$. bovis infected were suffering from highly rise in body temperature $\left(40-41^{\circ} \mathrm{C}\right)$, anaemia, various degrees of jaundice (icterus) from paleness in mild cases to severe yellow discoloration of conjunctival and vaginal

Table 2: Description of Primers for Babesia Species, Babesia bovis and Size of their Amplified Products

\begin{tabular}{|c|c|c|c|}
\hline Parasite & Primers & Primer sequences (from 5' to 3') & Expected amplicon size (bp) \\
\hline \hline Babesia spp. & $\mathrm{F}$ & TGGAACTTTAGGGTTTATACG & 644 \\
\hline Babesia spp. & $\mathrm{R}$ & GGTAATTACTCCATAAGTTA & \\
\hline Babesia bovis & $\mathrm{F}$ & GGGTTTATATAGTCGGTTTTGT & \\
\hline Babesia bovis & $\mathrm{R}$ & ACCATTCTGGTATATGC & \\
\hline
\end{tabular}

$F=$ Forward primer; $R=$ Reverse primer $T=$ Thiamine $; C=$ Cytosine; $A=$ Adenine $;=$ Guaninne. 
mucous membranes in more progressive cases, haemoglobinuria, and accelerated heart and respiratory rates. Various degrees of tick infestations with the different life stages of ticks were present around groins, horns, Inter-mandibular space, and ears. Giemsastained blood smears from the infected animals showed intra-erythrocytic piroplasms of $B$. bovis that were in the form of pyriform or pear-shaped. Out of 34 cattle and buffaloes, ME identified 13 animals (38.2\%) as $B$. bovis infected while 21 animals $(61.8 \%)$ were identified as negative. On the other hand, PCR identified 29 animals $(85.3 \%)$ as B. bovis infected while 5 animals $(14.7 \%)$ were identified as negative, Figures $(\mathbf{1}, \mathbf{2})$ and (Table 3 ). Out of 20 cattle, ME identified 8 cattle $(40 \%)$ as $B$. bovis infected whereas, PCR identified 17 cattle (85\%) as $B$. bovis infected. Out of 14 buffaloes, ME identified 5 buffaloes $(35.7 \%)$ as $B$. bovis infected whereas, PCR identified 12 buffaloes $(85.7 \%)$ as $B$. bovis infected. Out of 19 apparently healthy cattle and buffaloes, ME identified 5 animals $(26.3 \%)$ as $B$. bovis infected whereas, PCR identified 15 animals $(78.9 \%)$ as $B$. bovis infected. Out of 15 clinically infected cattle and buffaloes, ME identified 8 animals $(53.3 \%)$ as $B$. bovis infected whereas, PCR identified 14 animals $(93.3 \%)$ as $B$. bovis positive, (Table 3).

\section{DISCUSSION}

B. bovis is one of the most important blood parasites affecting cattle and buffaloes and in its acute forms, it lowers the productive performance of the affected animals $[25,26]$. It is estimated that 1.2 billion cattle are exposed to babesiosis in many countries of the world including Asia, Australia, Africa, South and Central America and the United States [27]. Clinical findings of $B$. bovis-infected cattle and buffaloes were mainly high fever $\left(40-41^{\circ} \mathrm{C}\right)$, dark brown to coffee urine (haemoglobinuria), accelerated respiratory rates, anemia, and various degrees of jaundice from paleness in mild cases to severe yellow discoloration of conjunctival and vaginal mucous membranes in more progressive cases with reduced appetite. These findings come in agreement with what was previously described [6, 28, 29]. It was noticed that the clinical symptoms on $B$. bovis-infected water buffaloes were less severe than those symptoms appeared on $B$. bovis-infected cattle. Water buffaloes and cattle with subclinical babesiosis in endemic regions become long-term carrier for piroplasms and these animals then become sources of infection for vector ticks. Therefore, latent infections are important in the epidemiology of babesiosis [30].

The diagnosis of ruminant piroplasmosis is generally based upon the microscopic examination of Giemsa stained blood smears and by clinical symptoms in acute cases. After acute infections, recovered animals frequently sustain subclinical infections, which are microscopically undetectable [31, 32]. They can be considered as a source of infection

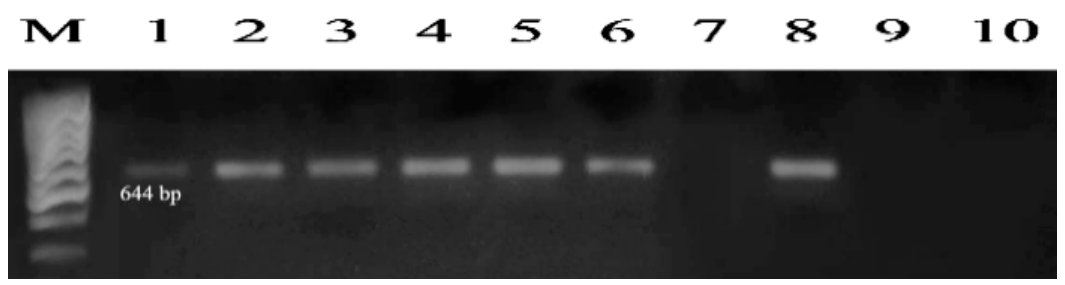

Figure 1: Agarose gel electrophoresis of amplified Babesia spp. DNA (644 bp) using primers common to Babesia spp. Lanes 2, 3, 4, 5, 6, 8 represent positive amplifications from field bovine blood samples; lanes 7, 9 and 10 represent negative amplifications from field blood samples; lane 1 represents positive control sample, and lane $M$ represents $1 \mathrm{~kb}$ DNA ladder as a standard size marker.

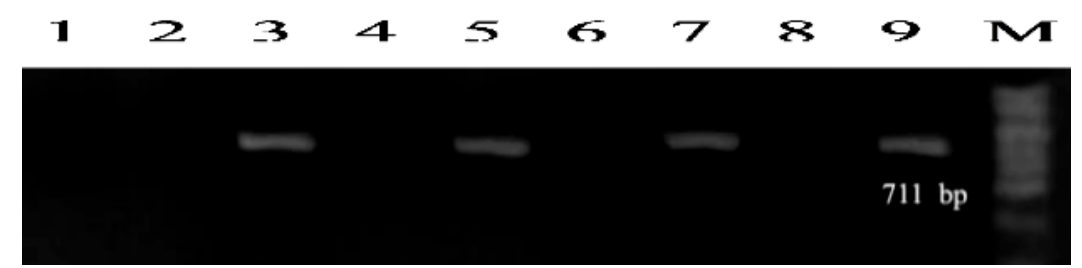

Figure 2: Agarose gel electrophoresis of amplified Babesia bovis DNA (711 bp) using primers specific to $B$. bovis. Lanes $3,5,7$ represent positive amplifications from field bovine blood samples; lanes 1, 2, 4, 6, 8 represent negative amplifications from field blood samples; lane 9 represents positive control sample and lane $M$ represents $1 \mathrm{~kb}$ DNA ladder as a standard size marker. 
Table 3: Results of PCR assay and microscopical examination (ME) for detection of Babesia bovis from clinically infected and apparently healthy crossbred cattle and water buffaloes from Sharkia Province of Egypt

\begin{tabular}{|c|c|c|c|c|c|c|}
\hline \multirow{2}{*}{ Species } & $\begin{array}{c}\text { Total examined } \\
\text { number }\end{array}$ & PCR/ME & PCR/ME & PCR/ME & PCR/ME & Total \\
\cline { 3 - 6 } & $+/ /+$ & $+/-$ & $-/+$ & $1(9 \%)$ & $11(32.4 \%)$ \\
\hline \hline \multirow{2}{*}{$\begin{array}{c}\text { Crossbred } \\
\text { cattle } \\
(\mathrm{N}=20)\end{array}$} & Clinically infected & $5(45.5 \%)$ & $5(45.5 \%)$ & 0 & $2(22.2 \%)$ & $9(26.5 \%)$ \\
\cline { 2 - 7 } & Apparently healthy & $3(33.3 \%)$ & $4(44.5 \%)$ & 0 & 0 & $4(11.7 \%)$ \\
\hline $\begin{array}{c}\text { Water } \\
\text { buffaloes } \\
(\mathrm{N}=14)\end{array}$ & Clinically infected & $3(75 \%)$ & $1(25 \%)$ & 0 & $2(20 \%)$ & $10(29.4 \%)$ \\
\cline { 2 - 7 } & Apparently healthy & $2(20 \%)$ & $6(60 \%)$ & 0 & $5(14.7 \%)$ & $34(100 \%)$ \\
\hline
\end{tabular}

for the potential vector causing natural transmission of the disease. In this study, the conserved primers for Babesia derived from SSU rRNA gene were used in PCR amplification for the detection of Babesia DNA, which amplified a fragment of $644 \mathrm{bp}$ in the examined bovine samples [10], Table 2. This pair of primers was not able to differentiate among members of Babesia species. Then, the primer pair specific for $B$. bovis was able to amplify an expected 711 bp PCR product Figure 2 and Table 2.

Regardless the presence or absence of clinical signs of babesiosis, PCR was more sensitive in the detection of $B$. bovis with $85.3 \%$ while ME identified only, $38.2 \%$. This could be argued by PCR work on detection of the DNA of $B$. bovis from the blood samples meanwhile ME based on the morphological characters of $B$. bovis for visual detection under microscope. This finding was in agreement with results of previous studies $[9,15,26]$. It is noticed that the prevalence of $B$. bovis in cattle $20 / 34(58.8 \%)$ was higher than the prevalence in buffaloes $14 / 34$ (41.2\%). Moreover, the prevalence in cattle with clinical signs $11 / 20(55 \%)$ was higher than the prevalence in buffaloes with clinical signs 4/14 (28.6\%). These finding suggest that water buffaloes are likely to have a natural tolerance to the parasite and/or more likely to be persistent carriers which were not picked up by microscopy, this comes in context with what was previously found [33] who stated that water buffaloes seem to be unapparent carriers for $B$. bovis. Out of 19 apparently healthy cattle and buffaloes, PCR detect 15 $(78.9 \%)$ while ME identified only $5(26.3 \%)$ as $B$. bovisinfected. This finding indicates the higher sensitivity of PCR for detection of animals with carrier state of $B$. bovis infection which were false diagnosed by ME as negative. Out of 15 clinically infected animals, PCR detect 14 (93.3\%) while ME identified only $8(53.3 \%)$ as $B$. bovis-infected, (Table 3 ). This finding is strong evidence that $\mathrm{PCR}$ is much more sensitive than ME either in clinically infected or apparently healthy animals (carriers), this comes in agreement with what was previously found [15, 34, 35]. In conclusion, our findings demonstrated that water buffalos are likely to have a natural tolerance to $B$. bovis pathogen and/or more likely to be persistent carriers which were not picked up by microscopy. The severity of clinical symptoms of $B$. bovis infection on water buffaloes was less than the severity of clinical symptoms on cattle. PCR show a higher sensitivity in detection of $B$. bovis false negative results of microscopical examination. PCR assay is more sensitive technique than microscopical examination for detection of $B$. bovis in both clinically and apparently health cattle and water buffaloes which suggests its use as a routine technique for diagnosis of bovine babesiosis.

\section{ACKNOWLEDGMENTS}

This study was accomplished and funded by Faculty of Veterinary Medicine, Zagazig University, Egypt. Author are grateful to Prof. Adel Goher at Department of Clinical Pathology, Faculty of Veterinary Medicine, Cairo University for his support.

\section{REFERENCES}

[1] Böse R, Jorgensen WK, Dalglies RJ, Friedhoff KT, De Vos AJ. Current state. Vet Parasitol 1995; 57: 61-74.

[2] Bock R, Jackson L, De Vos AJ, Jorgensen W. Babesiosis of cattle. Parasitol 2004; 129: 247-269. http://dx.doi.org/10.1017/S0031182004005190

[3] McCosker PJ. The global importance of babesiosis. In: Ristic M, Kreier JP, Eds. Babesiosis. Academic press, New York 1981; pp. 1-24.

[4] Papadopoulos B, Brossard M, Perié NM. Piroplasms of domestic animals. Vet Parasitol 1996a; 63: 57-66. http://dx.doi.org/10.1016/0304-4017(95)00845-4

[5] Kuttler KL. World-wide impact of babesiosis. In: Ristic, M. Ed., Babesiosis of Domestic Animals and Man. Boca Raton, Florida; 1988.

[6] Kaufmann J. Parasitic Infections of Domestic Animals, A Diagnostic Manual, Basel, Boston, Berlin, Birkhaüser, Birkhaüser Verlag; 1996. 
[7] Mahoney DF. Bovine Babesiosis. Ann Trop Med Parasitol 1969; 63: 1-14.

[8] Böse R, Jacobson RH, Gale KR, Waltisbuhl DJ, Wright IG. An improved ELISA. Parasit Res 1990; 76: 648-52.

[9] Calder JA, Reddy GR, Chieves L, et al. Monitoring Babesia bovis. J Clin Microbiol 1996; 34: 2748-55.

[10] Salem GH, Liu XJ, Johnsrude JD, Dame JB, Roman Reddy GR. Development and evolution. Molecular Cell Probes 1999; 13: 107-13. http://dx.doi.org/10.1006/mcpr.1998.0223

[11] Papadopoulos B, Perié NM, Uilenberg G. Piroplasms of domestic animals. Vet Parasitol 1996b; 63: 41-56. http://dx.doi.org/10.1016/0304-4017(95)00878-0

[12] Buening GM, Barbet AF, Myler $P$, Mahan S, Nene V, McGuire TC. Characterization of a repetitive DNA. Vet Parasit 1990; 36: 11-20. http://dx.doi.org/10.1016/0304-4017(90)90089-T

[13] Jasmer DP, Reduker DW, Goff WL, Stiller D, McGuire TC. DNA probes. J Parasitol 1990; 76: 834-41. http://dx.doi.org/10.2307/3282802

[14] Figueroa JV, Alvarez JA, Rojas EE, et al. Use of a duplex PCR/DNA. Rev Latinoam Microbiol 1998; 40: 39-44.

[15] Fahrimal Y, Goff WL, Jasmer DP. Detection of Babesia bovis J Clin Microbiol 1992; 30: 1374-9.

[16] Nagati HE. Some new and rare records. Vet Rec 1947; 59: 145-7.

[17] Adham FK, Abd-El-Samie EM, Gabre RM, Hussein HEI. Detection of tick blood parasites in Egypt using PCR assay I-Babesia bovis and Babesia bigemina. Parasitol Res 2009; 105: 721-30.

http://dx.doi.org/10.1007/s00436-009-1443-8

[18] Somparn P, Gibb MJ, Markvichitr K, Chaiyabutr N, Thummabood S, Vajrabukka C. Analysis of climatic risk. Int J Biometeorol 2004; 49: 59-64.

[19] Iseki H, Zhou L, Kim C, et al. Seroprevalence of Babesia infections. Vet Parasitol 2010; 170: 193-6. http://dx.doi.org/10.1016/j.vetpar.2010.02.038

[20] Mahmoud MS, Abou-Zeina HAA. Current State in the Serological. Global Veterinaria 2008; 5: 271-81.

[21] Saleh MA. Erythrocytic oxidative damage ResVet Sci 2009; 86: 43-8.

http://dx.doi.org/10.1016/j.rvsc.2008.05.005
[22] Kelly R. Veterinary Clinical Diagnosis. 2nd edition, Bailliere Tindall, London 1979.

[23] Rosenberger G. Clinical Examination of Cattle. Verlag Paul Parey, Berlin/Hamburg 1990.

[24] Sambrook J, Fritsch, Maniatis T. Molecular cloning: a laboratory manual cold spring Harbour laboratory press, New York 1989.

[25] Talkhan OFA, Radwan MEI, Ali MA. Cattle Babesiosis Nat Sci 2010; 12: 24-7.

[26] Ziapour SP, Esfandiari B, Youssefi MR. Study of the prevalence of babesiosis. J Animal Veterin Adv 2011; 10 712-4

[27] Terkawi MA, Thekisoe OMM, Katsande C, et al. Serological survey of Babesia bovis. Vet Parasitol 2011; 182: 337-42. http://dx.doi.org/10.1016/j.vetpar.2011.05.047

[28] Georgi JR, Georgi ME, Theodrides VJ. Parasitology for Veterinarians $5^{\text {th }}$ ed., W. B. Saunders Company. Harcourt Brace Jovanovich, Inc. Philadelphia; 1990.

[29] Brown C. Foreign animal diseases. Boca Raton, Florida United States Animal Health Association; 2008.

[30] Figueroa JV, Chieve LP, Johnson GS, Goff WL, Buening GM. Polymerase chain reaction. Rev Latinoam Microbiol 1994; 36: 47-55.

[31] Perez-Llaneza A, Caballero M, Baravalle $F$, et al. Development of a tandem. Vet Parasitol 2010; 167: 196-204. http://dx.doi.org/10.1016/j.vetpar.2009.09.021

[32] Schneider DA, Yan IH, Bastos RG, et al. Dynamics of bovine spleen cell. Parasite Immunol 2011; 33: 34-44. http://dx.doi.org/10.1111/j.1365-3024.2010.01249.x

[33] Ferreri L, Benitez D, Dominguez M, et al. Water Buffalos as carriers. Ann N Y Acad Sci 2008; 1149: 149-51.

http://dx.doi.org/10.1196/annals.1428.036

[34] Aktas M, Dumanli N, Cetinkaya B, Cakmak A. Field evaluation of PCR. Vet Rec 2002; 150: 548-9. http://dx.doi.org/10.1136/vr.150.17.548

[35] Altay K, Aktaş M, Dumanli N. Survey of T. annulata. Turkiye Parazitol Derg 2007; 31: 94-7. 